\title{
Mexico's market reforms in historical perspective
}

\author{
Juan Carlos Moreno-Brid and Jaime Ros
}

$\mathrm{T}$

his paper examines Mexico's main economic policies and problems during the last two centuries. Focusing on episodes of radical shifts in development strategy concerning the role of the market and the State, it argues that Mexico's real obstacles to development have often been misperceived, and such misperception may be occurring today. This argument is tested, initially, by reviewing the causes of Mexico's economic stagnation during most of the nineteenth century. The period of economic expansion between 1940 and 1981, which ended with the collapse of the oil boom in 1981 is also examined. A critical review is made of the radical shift in development strategy implemented in the mid-1980s in response to the external debt crisis associated with the apparent exhaustion of the strategy of import substitution and State-led industrialization. Finally, some thoughts are presented on the current 


\section{I}

\section{Introduction}

This paper looks at Mexico's development policies and problems from a historical perspective. It reviews longterm trends in the Mexican economy, with particular attention to some past episodes of radical shifts in development strategy and in the role of the market and the State, especially in the last twenty years. A major theme is that the real obstacles to economic development have often been misperceived in the past and that the same may be happening at present. The paper is organized as follows. After a brief introduction, section II reviews the debates on the causes behind Mexico's long period of economic stagnation during most of the nineteenth century. Section III examines the long period of expansion of the Mexican economy that began with the Porfiriato, ${ }^{1}$ in the late nineteenth century, and ended with the collapse of a short-lived oil boom in 1981. Section IV focuses on the performance of the Mexican economy after the radical shift in development strategy in the mid-1980s. The paper ends with some thoughts on the challenges facing the Mexican economy today, when after almost two decades of far-reaching economic reform it is still not able to embark on a process of sustained rapid growth. Even worse, for the first time in its modern history it is about to experience three successive years of absolute decline in its real per capita GDP.

\section{II}

\section{The market reforms in the nineteenth century}

By the end of the $18^{\text {th }}$ century Mexico was probably one of the most prosperous regions in the world. It was surely one of the wealthiest Spanish colonies in America, with an economy whose productivity was possibly higher than that of Spain herself. Output per capita (in 1800) was around half that of the United States, and Mexico's economy was less agricultural, with an advanced mining industry and a significant manufacturing sector. The value of the country's exports was similar to that of its northern neighbour, even though the total output produced was around half (Coatsworth, 1978). Several of the conditions for rapid capitalist development were in place. The creation of

This paper is an extended and revised version of an essay published by the authors nearly ten years ago, at the time that the North American Free Trade Agreement (NAFTA) was put in place (see Moreno-Brid and Ros, 1994). It was presented at the Latin American and Caribbean Economic Association (LACEA) meeting in Cholula, Mexico, on 10 October 2003. The authors wish to acknowledge the valuable research assistance of Rubén Guerrero and the comments on a previous version made by Ted Beatty, Rolando Cordera, Amitava Dutt, Julie Lennox, Ajit Singh, Carlos Tello, Samuel Valenzuela and Jeff Williamson. The opinions expressed herein do not necessarily coincide with those of the United Nations. an industrial labour force - that 'most difficult and protracted process' by which the population's ties to the land are broken (Gerschenkron, 1952) — although far from complete, was probably more advanced than in many European countries (especially in Central and Eastern Europe). The relatively high share of manufacturing in total output in 1800 (22.3\%, see table 1$)^{2}$ also indicates the presence of a critical mass of native industrial entrepreneurs (table 1).

\section{Mexico's Century of Decline (1780-1870): obstacles to economic development}

This favourable position of the Mexican economy began to deteriorate in the last few decades of the $18^{\text {th }}$ century, however. Although the exact moment at which this deterioration began is a matter for debate, it is generally agreed that Independence did nothing to prevent the stagnation of the economy during the half century that followed. Thus, between 1800 and

\footnotetext{
${ }^{1}$ Mexican historians give this title to the 33-year dictatorship of Porfirio Díaz (1877-1910).

${ }^{2}$ According to INEGI (1985), in 1790 the share of manufacturing employment was $10 \%$.
} 
TABLE 1

Mexico: Gross domestic product per capita and by sector, 1800-1910

\begin{tabular}{|c|c|c|c|c|c|c|}
\hline & 1800 & 1845 & 1860 & 1877 & 1895 & 1910 \\
\hline \multicolumn{7}{|l|}{ Per capita GDP at constant } \\
\hline 1900 prices $($ index $1800=100$ ) & 100.0 & 78.4 & 70.9 & 85.0 & 128.8 & 190.2 \\
\hline \multicolumn{7}{|l|}{$\%$ of GDP } \\
\hline Agriculture $^{\mathrm{a}}$ & 44.4 & 48.1 & 42.1 & 42.2 & 38.2 & 33.7 \\
\hline Mining & 8.2 & 6.2 & 9.7 & 10.4 & 6.3 & 8.4 \\
\hline Manufacturing & 22.3 & 18.3 & 21.6 & 16.2 & 12.8 & 14.9 \\
\hline Construction & 0.6 & 0.6 & 0.6 & 0.6 & 0.6 & 0.8 \\
\hline Transportation & 2.5 & 2.5 & 2.5 & 2.5 & 3.3 & 2.7 \\
\hline Commerce & 16.7 & 16.9 & 16.7 & 16.9 & 16.8 & 19.3 \\
\hline Government & $4.2^{\mathrm{b}}$ & 7.4 & 6.8 & 11.2 & 8.9 & 7.2 \\
\hline Other & 1.1 & - & - & - & 13.1 & 12.9 \\
\hline
\end{tabular}

Source: Coatsworth (1989), tables 4 and 5.

a Includes livestock, forestry and fishing.

b Excludes net fiscal remittances to the Spanish Treasury. Total government revenues, including these remittances, amounted to $7.8 \%$ of colonial income.

TABLE 2

Mexico: Total and per capita GDP and population, 1820-1998

\begin{tabular}{|c|c|c|c|c|c|c|c|}
\hline & 1820 & 1870 & 1913 & 1950 & 1973 & 1990 & 1998 \\
\hline Per capita GDP ${ }^{a}$ & 759 & 674 & 1732 & 2365 & 4845 & 6097 & 6655 \\
\hline \multirow[t]{2}{*}{ GDP gap (Mexico/United States) } & 0.60 & 0.28 & 0.33 & 0.25 & 0.25 & 0.26 & 0.24 \\
\hline & & $1820-1870$ & $1870-1913$ & $1913-1950$ & $1950-1973$ & 1973-1998 & \\
\hline Per capita GDP growth rates $(\%)$ & & -0.2 & 2.2 & 0.9 & 3.2 & 1.3 & \\
\hline Total GDP growth rates $(\%)$ & & 0.4 & 3.4 & 2.6 & 6.4 & 3.5 & \\
\hline Population growth rates $(\%)$ & & 0.7 & 1.1 & 1.8 & 3.1 & 2.2 & \\
\hline
\end{tabular}

Source: Maddison (2001).

a Dollars at 1990 international prices.

approximately 1860 - at the time when the United States and other now developed economies were recording unprecedented rates of economic growththe total product of Mexico fell by 5\% and per capita income declined by as much as $30 \%$. Between 1820 and 1870, Mexico's per capita income fell from $60 \%$ to $28 \%$ of that of the United States, and has since then fluctuated between $24 \%$ and $33 \%$ (table 2).

Why didn't independence and the emergence of a national State provide greater stimuli to economic development? Perhaps the most important reason was the prolonged period of political instability and continuous struggle between the conservative and liberal factions. ${ }^{3}$ Half a century of civil and international wars annihilated the potentially beneficial effects of independence, while at the same time curtailing the resources needed for the State and the private sector to support the recovery of the mining sector and improve the transport infrastructure in a country where the lack of natural communications and the resulting high transport costs had highly adverse effects on the division of labour and regional specialization (Coatsworth, 1990).

\footnotetext{
${ }^{3}$ In the 55 years between independence and the Porfiriato, the presidency changed hands 75 times (Haber, 1989). The most disastrous consequence of the prolonged civil strife was the loss to the United States of half of the national territory in the mid-19th century. Fifty years after the 1848 Treaty which ended the United States-Mexico war, and also after the beginning of the California "Gold Rush", the mineral output of the lost territories alone exceeded Mexico's total GDP (Coatsworth, 1978).
} 
Independence eliminated the fiscal burden on the gold and silver extracted from the colony. This had been a substantial burden - estimated by Coatsworth at $7.2 \%$ of total output around 1800 - much higher, for example, than the burden of British colonialism on its North American colonies. Yet the end of Spanish rule also brought some unexpected costs for the mining sector that partly offset the removal of this burde. ${ }^{4}$ As a consequence, silver production fell to less than onefifth of its initial level between 1812 and 1822, and the mining sector did not recover its pre-independence level of production until the 1860s (Cárdenas, 1985). The depression of silver production had, in turn, other important consequences for the economy. Besides the contraction of all the activities linked to the mining sector, it implied a reduction in the volume of international trade and a decrease in the means of payment available in the domestic economy (Cárdenas, 1985). This aggravated the consequences of the capital flight brought about by the exodus of Spanish miners and merchants, and thus the general lack of financial capital which characterized this period up to the 1860 s, when the first commercial banks were founded.

The abolition of restrictions on foreign trade also turned out to be a mixed blessing. While generally regarded by economic historians as beneficial for the Mexican economy, the end of trade restrictions accelerated the diversion of Mexican foreign trade away from Spain and towards the emerging industrializing powers in the North Atlantic: a trend which had very harmful effects on domestic manufacturing and, therefore, on the main activity that could have compensated for the decline of the mining sector. Several studies have documented how exposure to United States and British competition led to the collapse of the wool textile industry at the turn of the century and to the prolonged decline of cotton textiles throughout the first half of the 19th century. Trade openness towards the Atlantic economy and foreign competition - which in fact started in the period of 'comercio libre' and 'comercio neutral' introduced by the Bourbon reforms- also appears to have deepened the fragmentation of local markets and the cleavage between, on the one hand, a mining and

\footnotetext{
${ }^{4}$ Not only were the direct effects of the independence wars on mining production highly disruptive, but they also involved the loss of low-cost guaranteed supplies of mercury (essential for processing low-grade ores) that Spain had provided from its big State-owned mine at Almadena.
}

agricultural North trading with the rest of the world and, on the other, a manufacturing Centre and agricultural South plunged into economic depression (Thomson, 1986).

In addition, little progress was made in other areas. The colony had been one of the regions in the world with the sharpest social and regional disparities: a caste society, in fact, where access to employment as well as geographical and occupational mobility were restricted on the basis of ethnic distinctions, and where a number of institutional arrangements tended to increase, rather than reduce, the gap between the private and social benefits of economic activity. Although some changes did take place with independence, ${ }^{5}$ many of these had little effect in a backward social and political order. The ultimate reason is probably the nature of the foundational act of the post-independence State: the fact that having begun and been defeated as a popular insurrection - feared by both the Spanish and Creole conservative elites - independence came eventually to Mexico through 'a virtual coup d'état by the colony's Creole elite, carried out largely to separate Mexico from the liberalizing process under way in the mother country' (Coatsworth, 1978).

This had several consequences. Institutional modernization was de facto and sometimes de jure slow. A new civil code was only produced in 1870 —almost 50 years after independence — and even then nothing replaced a repudiated commercial code. The colonial mining code remained almost intact until 1877. Modern banking and patent laws were nonexistent. In spite of the provisions of the Constitution, taxes and restrictions on domestic trade remained.

The system of government preserved the arbitrary nature of political power in colonial times. Economic success or failure depended directly on the relationship between the enterprise and the political authorities (Coatsworth, 1978, p. 94). In sum, while economic activity remained 'State-centered', in the sense that 'every enterprise was forced to operate in a highly politicized manner', the State, compared to colonial

\footnotetext{
${ }^{5}$ Ethnic distinctions in access to employment, justice and fiscal treatment — which, among other things, had severely restricted capital and labour mobility - were formally abolished; many corporate privileges, including most of the guilds, were eliminated, while corporate property rights were limited to the Church and the Indian communities and town councils. The number of royal monopolies on the production and distribution of many commodities was reduced and their activities regulated; efforts were also made to modernize the judiciary and revise archaic judicial codes.
} 
times, had in fact been weakened and was unable to remove the obstacles to economic development resulting from the decline of mining activity, foreign competition, and the lack of transport infrastructure and financial capital. Economic and industrial stagnation therefore followed, as a consequence of the persistent lack of markets and their fragmentation.

\section{Liberal misperceptions in the mid-nineteenth century?}

This list of obstacles to economic development in 19th century Mexico is equally significant for what it excludes. Thus, recent revisionism by economic historians suggest that two of the traditional culprits - the land tenure system and the economic power of the Church- were not in fact among the major causes of economic stagnation during this period.

The system of land tenure and agricultural production had been organized since the 17th century into large estates called 'haciendas'. While highly inequitable and, to this extent, socially and macroeconomically inefficient, the hacienda system was far from a semi-feudal organization that encouraged waste and misallocation of resources. Recent research has produced a new image of the hacienda as a capitalistic and technologically dynamic undertaking with an economic rationality comparable to that of a modern agricultural enterprise, and one which extensively exploited its comparative advantages - economies of scale, and access to external credit and information on new technologies and distant markets. ${ }^{6}$ A 'division of labour' had, in fact, been established through time between the hacienda and other forms of agricultural production - small landowners, tenant farmers or Indian villagers - whereby each of them had specialized in those products and crops where they enjoyed a competitive advantage: cattle, sheep, wool, food grains, pulque, sugar and sisal in the haciendas, and fruits, tomatoes, chiles, silk and small animals such as pigs and poultry in the villages and small-scale producers.

A similar revisionism of traditional judgments applies to the Church as an economic institution. By the middle of the 19th century, the Church had become the country's largest single landowner and an important lender in the emerging financial markets. With respect to its first role, according to Coatsworth (1978 and

\footnotetext{
${ }^{6}$ See, among others, Van Young (1981 and 1986).
}

1990) several studies suggest that Church haciendas were at least as well managed as private haciendas; and, in any case, after independence most of these estates were rented to private farmers and hacienda owners, so that their efficiency did not depend on Church administration. On the other hand, the Church appropriated the tithe ('diezmo'), a $10 \%$ tax on gross output, levied mainly on agricultural and livestock production. Like any other tax, the tithe reduced the profitability of agricultural production and probably discouraged it (although some authors have doubts about this). ${ }^{7}$ More important, however, is the use to which these revenues were put. Far from financing wholly 'unproductive' expenditures, the Church invested a considerable portion of its revenues (including also private donations and net income from its various properties) in loans to private entrepreneurs with no legal or practical restrictions to prevent recipients from investing in factories rather than haciendas or other activities. In doing this, it lent at below-market interest rates -usually at a rate of $6 \%$ on loans secured with real property. Because it dominated the mortgage-lending market, this probably had the effect, in turn, of bringing market interest rates down. As Coatsworth (1978) has put it, the Church acted like a modern development bank, raising the rate of capital accumulation above what it would have been in the absence of the tithe.

If this revisionist approach by economic historians is correct, then some of the main elements of the liberal economic programme - free trade, the privatization of corporate and public property, and the liberalization of the land market- were largely misdirected from a strictly (and admittedly narrow) economic development perspective. The first (free trade) probably gave a further stimulus to the decline of local manufacturing - and to the 'ruralization' of the labour force - as the expansion of railways in the late 19th century sharply reduced the natural protection provided by traditionally high transport costs. The second, the privatization of corporate property, had the effect of destroying the major, and for a long time practically the only, banking institution in the economy; while the third, the

\footnotetext{
${ }^{7}$ See, in particular, García Alba (1974) and Coatsworth (1978) The reason is that the effect of the tithe in pushing labour and capital out of private agriculture was probably very small because the Church itself, and the Indian villages, produced a major portion of the country's farm products and livestock. In any case, the net effect on GDP was probably positive, since differences in productivity between private agriculture and the rest of the economy suggest that non-agricultural activities were already more productive than agriculture.
} 
liberalization of the land market, was to contribute to further land concentration and, eventually, to the social explosion of 1910.

This does not mean, of course, that the conservative faction was any better. Although some of its members, Lucas Alamán in particular, had the merit of pioneering the first, and short-lived, industrialization efforts in the 1830s - through industrial protection and the creation of the first public development bank (Banco de Avío) to finance the development of the textile industry -8 the social and political forces that supported them tended to perpetuate the same arbitrary centralism of political power that had had such harmful effects on economic development since colonial times.
As a result, the coalition that could have forged a developmental State did not emerge, and in its absence, some of the main obstacles to economic development remained in place. The liberals who could and were willing to carry out the country's political and social modernization were also furiously anti-Statist in economic terms; while the only ones who favoured economic modernization through an interventionist State were the conservatives, who were strongly opposed to political and social modernization. It would take a social explosion and a popular revolution in the early 20th century to bring these two requirements for economic development into a less conflictive relationship.

\section{III}

\section{The traumatic emergence of a Gershenkronian developmental State}

\section{The Porfiriato: political stability and the emergence of a unified national market}

In practice, modern economic growth began in the late $19^{\text {th }}$ century. ${ }^{9}$ In $1895,72 \%$ of the population lived in rural areas and more than $80 \%$ of those aged ten and above could not read or write (table 3 ). In 1877, when Porfirio Díaz seized power, $42 \%$ of Mexico's GDP was generated by rural activities and only $16 \%$ by manufacturing (table 1). In the following two decades, a turnaround in Mexico's long-term decline gradually became evident. The barriers to economic recovery were brought down by the transformation of the international economic environment and the internal changes in Mexico's political and economic structure that took place under the dictatorship of Porfirio Díaz (1877-1910), a 33-year period of political stability aptly named the Porfiriato by Mexican historians.

Melding a liberal political background with conservative economic goals, the Porfiriato's ideology is summarized in the positivist slogan of "Order and Progress". Order was considered a sine qua non for

\footnotetext{
${ }^{8}$ Another figure worth mentioning is Estevan de Antuñano, a creole industrialist, whose many pamphlets best articulated the case for protectionism and industrialization.

${ }_{9}^{9}$ For statistics of economic growth during the Porfiriato, see Beatty (2001), Rosenzweig (1965), and Solís (2000).
}

economic growth. The end of the military and political struggles that had plagued Mexico since its independence was seen as an essential pre-condition for business confidence and the recovery of private investment. Strengthening of the central government was efficiently pursued, and by combining the use of force and alliances with relevant groups, Díaz was able to take full hold of the political structure.

Progress, for its part, meant transforming Mexico into an industrialized nation by effectively addressing some of the traditional barriers to economic recovery, such as the lack of transport infrastructure and financial capital. ${ }^{10}$ To foster the expansion of the railway network, the State awarded concessions and financial incentives. The subsidies granted for railway construction amounted to $50 \%$ of the total cost. The expansion of the railway system enormously amplified the size of the market, brought down local and regional trade barriers, and intensified competition. ${ }^{11}$ This effect

\footnotetext{
${ }^{10}$ The importance of these obstacles to economic development was well recognized at the time. In the words of Matías Romero: "This nation...has in its soil immense treasures of agricultural and mineral wealth, which cannot currently be exploited due to the lack of capital and communications.." (cited by Rosenzweig, 1965).

${ }^{11}$ The railway system expanded from $900 \mathrm{~km}$ to $19,000 \mathrm{~km}$ in the 1880s. According to Coatsworth's estimates, this brought an $80 \%$ reduction in freight costs per kilometer between 1878 and 1910.
} 
Mexico: Population and social indicators, 1895-2000

\begin{tabular}{|c|c|c|c|c|c|}
\hline Year & $\begin{array}{l}\text { Total population } \\
\text { (millions) }\end{array}$ & $\begin{array}{l}\text { Rural population } \\
\text { (per cent) }\end{array}$ & $\begin{array}{l}\text { Life expectancy } \\
\text { at birth (years) }\end{array}$ & $\begin{array}{l}\text { Literacy } \\
\text { (per cent) }\end{array}$ & $\begin{array}{c}\text { Average years } \\
\text { of schooling }\end{array}$ \\
\hline 1895 & 12.6 & 72 & 30 & $17.9^{\mathrm{c}}$ & $\ldots$ \\
\hline 1910 & 15.2 & $\ldots$ & $\ldots$ & 27.7 & $\ldots$ \\
\hline 1930 & 16.6 & 66.5 & 33.9 & 38.5 & $\ldots$ \\
\hline 1940 & 19.7 & 64.9 & 38.8 & 41.8 & 2.6 \\
\hline 1980 & 68.3 & 33.7 & 66.2 & $83.0^{c}$ & 4.6 \\
\hline 1990 & 81.2 & 28.7 & 70.8 & 87.4 & 6.6 \\
\hline 1995 & 91.2 & 26.5 & 73.6 & 89.4 & 7.2 \\
\hline 2000 & 97.0 & 25.4 & 75.3 & $90.3^{b}$ & 7.6 \\
\hline
\end{tabular}

Source: Maddison (1989) and INEGI (various years).

a Population age 10 or above.

b Age 15 or above.

c Age 6 or above.

was reinforced by the significant improvement in the safety of road travel achieved by the Díaz regime.

Foreign investment was another key aspect of Díaz's development strategy, and was actively sought after through various incentives. These inducements and the profitable investment opportunities that existed led to an inflow of foreign capital. From 1880, United States capital flowed in, later followed by European investments (Coatsworth, 1989). These flows increased continuously for the next 15 years, and boomed in particular in the first decade of the 1900s (King, 1970). More generally, State policies were geared to promote private investment and guarantee the best conditions for its operation. The legal framework for the conduct of private business was soon transformed. In 1883 new legal codes for trade and mining were adopted to improve the conditions for private investment. Regional taxes on domestic trade were abolished. Trade policy combined focused tariff protection consistent with supporting industrialization in the consumer goods sectors and a reduction in average tariffs that enhanced manufacturers' access to low-cost capital and intermediate goods (Beatty, 2002; Kuntz Ficker, 2002).

Foreign investment meant access to world markets, and between 1870 and 1913 Mexico's exports increased threefold as a share of GDP. The expansion of foreign trade also helped to increase government resources, as taxes on foreign trade provided more than half of public revenues. Greatly helped by the depreciation of silver at the end of the 19 th century, ${ }^{12}$

12 The depreciation of silver was provoked by the adoption of the Gold Standard towards 1870 in the advanced countries (Cárdenas the export sector became an engine of growth, as it had been in colonial times. This time the export basket was considerably more diversified than in the colonial period, as it included, besides silver, other minerals -industrial metals such as copper, lead and zinc, demand for which by the industrial centers of the world economy was expanding rapidly — as well as a number of agricultural products (coffee, livestock and others which were added to others that were already of some importance in the composition of exports such as henequen, furs and wood). Accompanying these policy changes and the responses to them was a more propitious external economic environment. By 1870 the second industrial revolution in the industrialized countries had spurred demand for minerals and other raw materials. Combined with the end of political instability, the new environment helped to restore international creditworthiness. ${ }^{13}$

What was the overall outcome of this strategy in terms of development? Economic growth and

and Manns, 1989). It amounted to a continuous real devaluation of the Mexican peso by $26 \%$ up to the beginning of the 1890 s. See Zabludovsky (1984), who assesses both the view, held by Rosenzweig (1965) and Nugent (1973), that devaluation promoted export-led growth, and the purchasing power parity-based view of Limantour (Porfirio Díaz's Minister of Finance), according to which the depreciation of silver was ultimately reflected in the price level. Zabludovsky's (1994) evaluation of the evidence supports the first view. 13 After having defaulted on its external debt on six different occasions between 1824 and 1880, in 1889 the Mexican government finally reached an agreement with foreign bankers on rescheduling Mexico's foreign debt. By the early 1890s, the country's access to international capital markets was restored and, between then and 1911, Mexico's external debt increased $300 \%$, mostly to finance public works in infrastructure. 
modernization was felt in many areas, reversing a century of decline, and from 1877 to 1910 Mexico's per capita GDP increased at an annual average rate of $2.1 \%{ }^{14}$ The railroad boom benefited some traditional activities — such as mining — ${ }^{15}$ and at the same time helped in the creation of new activities whose production scales and capital intensity had made them unprofitable in the absence of a unified national market. Indeed, underlying this modernization was Mexico's first wave of large-scale industrialization. Through import substitution in textiles, beer, papermaking, cement and steel, manufacturing output increased at an average rate of $3.6 \%$ per annum from 1877 to 1910 (Coatsworth, 1989). Manufacturing changed from being an artisanal activity, carried out in small handicraft workshops, to a productive process undertaken in large-scale plants. The rural areas were also deeply transformed in their social and economic structure. Based on a diagnosis of the rural sector as unproductive, with most agricultural output distributed through non-market channels, the Díaz administration promoted an accelerated process of redistribution of federal and communal land to private development companies and wealthy individuals. Such privatization would promote large-scale commercial cultivation. By $1890,20 \%$ of Mexico's total area was held by less than 50 individuals or companies. By the early 1900 s, $95 \%$ of all arable land was in the hands of 835 families (Manzanilla Schaffer, 1963).

By the early 1900s, however, this pattern of development started to show symptoms of exhaustion. From 1903 on, real wages began to decrease in a systematic and persistent way. Droughts in 1907 reduced the output of food products, and furthermore increased their prices. By 1910, the cumulative decline in real wages was $26 \%$ relative to 1903 . Although there were no clear signs of famine, poverty was widespread, especially in rural areas. ${ }^{16}$ At the same time, the use of force to repress labour and suppress political opposition became more frequent and eventually unsuccessful. By 1910, the system's unequal distribution of benefits and access to power reached its

\footnotetext{
${ }^{14}$ See Bortz and Haber (2002).

${ }^{15}$ Mining would most likely have remained abandoned without the railway expansion, as neither the necessary capital inputs for its development nor the commercialization of mineral products would have been profitable.

${ }^{16}$ As noted by Haber (1989), the extent of poverty was such that the increase in the price of maize due to a bad harvest was capable of reducing workers' consumption of manufactures by enough to provoke a crisis in the cotton garment industry.
}

limit. The emerging middle classes excluded from political decisions, and the workers and peasants marginalized from the benefits of economic growth, were successful in developing a triumphant coalition under the banners of political democracy, agrarian reform and labour rights.

What had gone wrong? Clearly, the Porfiriato's 'primary contradiction' was in its results: the growing imbalance between rapid economic growth, on the one hand, and the slow pace of political and social progress on the other. Porfirio Díaz had set out to make Mexico into a modern industrial nation, but by 1910 only $28 \%$ of Mexicans could read and write, and life expectancy at birth was not much more than 30 years (table 3). With two-thirds of its population still living in rural areas, Mexico had still a fundamentally backward economy and, overall, a backward society. Moreover, while the emergence of a national market had broken through some of the barriers of stagnation, the limited role of the State proved insufficient to overcome the still enormous obstacles to economic development. ${ }^{17}$

\section{Revolution and the consolidation of a developmental State}

In 1910 the "Pax Porfiriana" came to a dramatic close with the Mexican Revolution. Once more, the absence of social consensus became the fundamental obstacle for Mexico's development. The construction of a stable social pact would be fully achieved only three decades later.

The most violent stages of the Mexican Revolution ended with the adoption of a new Constitution in 1917. Political unrest continued for the next ten years -marked by the killing of important figures such as Zapata, Carranza and Obregón, and numerous uprisings - but the scale of the armed struggle diminished significantly. The 1917 Constitution redefined the legal framework for land ownership and labour relations. It placed the nation over and above private property in matters regarding land, water and subsoil resources; established the right to form trade unions, a system of minimum wages, eight-hour workdays within a six-day workweek, and equal pay for equal work; and included agrarian reform through the expropriation of large land holdings and the

\footnotetext{
17 Public investment never amounted to more than 5\% of total investment, and only $7 \%$ of public expenditure was directed at capital formation purposes.
} 
allocation of this land to 'ejidos', a land tenure system combining collective ownership with private exploitation of the land.

A fundamental move towards the consolidation of social peace and political stability was the creation of the Partido Nacional Revolucionario (PNR) in 1929.18 Renamed Partido de la Revolución Mexicana (PRM) in 1938 and Partido Revolucionario Institucional (PRI) in 1946, this official party encompassed all the important social forces of the Mexican Revolution and soon became a functional vehicle for political control and the only legitimate arena in which to settle political differences. By the 1940s, the age of Caudillos was over, and Mexico's particular form of institutionalized authoritarian control had begun.

The process of consolidation of political power after the Revolution was accompanied by an expansion in the policy instruments available to the government. ${ }^{19}$ Under the presidency of Cárdenas (1936-1940), the public sector expanded further, with the creation of several development or financial entities. Most important, the oil industry was nationalized and agrarian reform began to be implemented on a massive scale. Fiscal policy became counter-cyclical and budget deficits were run to boost productive and social investment. Public expenditure was reoriented away from military and administrative spending. The highway system increased sevenfold, reaching 9,900 $\mathrm{km}$ by 1940 . In addition, temporary flotation of the exchange rate led to a depreciation of the peso in real terms.

With the turnaround in the conduct of government policies and the extraordinary recovery in the terms of trade in silver and oil (the country's main exports), Mexico resumed growth in 1933-34. The first new round of investment since the Porfiriato began in manufacturing and was concentrated in new textile activities. Manufacturing became the most dynamic sector of the economy.

\footnotetext{
${ }^{18}$ For detailed accounts of the creation of the PNR and its role in long-term political stability, see Newell and Rubio (1984).

19 The Bank of Mexico was established in 1925, and started to operate as a central bank in the early 1930s as a response to the Depression. By then, the National Agricultural Credit Bank had been established, and the creation of other banks followed. In 1933, the Budget Ministry created the National Finance Entity, which was soon to become the Nacional Financiera: the first fully-fledged development bank and the financial pivot for industrial and other long-term investment.
}

\section{The post-war Golden Age of industrialization (1940-1980)}

In the process of achieving hegemony, the Mexican State arrived at a strong conviction that it should play an active role in investment and production if Mexico was to develop. By the late 1940s, it controlled fundamental resources and had increased the number of its policy instruments significantly. Public investment expanded systematically (table 4) and was oriented towards urban and industrial development. Additional incentives such as tax concessions were used to promote manufacturing activities. Investments in education and welfare maintained their share in federal expenditure. The industrialization drive also came hand in hand with a deepening of trade protection, and by 1947 protectionism had been officially adopted as a government intermediate objective.

A complete overhaul of the economy and society took place between 1940 and 1980. Mexico's economy grew at a sustained pace of $6.4 \%$ per annum in real terms, while per capita GDP grew by $3.2 \%$ per annum. Manufacturing became the engine of growth, with rates of growth of production of $7.4 \%$ per annum from 1940 to 1955 , and it further accelerated its pace of development from 1957 to 1970, expanding at annual rates of $8.9 \%$, with the dynamic domestic market as its major source of demand. The country was transformed from an agrarian one into an urban, semiindustrial society. Between 1940 and 1980, the share of manufacturing in the product rose from $15.4 \%$ to $24.9 \%$ (table 5) and the share of the population living in urban areas soared from $35 \%$ to $66 \%$, while total population increased from 20 to 70 million people (table 3). Literacy rates nearly doubled, reaching 83\%

TABLE 4

Mexico: Investment rates, 1900-1980

\begin{tabular}{lcc}
\hline Year & $\begin{array}{c}\text { Total investment } \\
(\% \text { of GDP })\end{array}$ & $\begin{array}{c}\text { Public investment } \\
(\% \text { of GDP })\end{array}$ \\
\hline 1900 & 10.1 & $0.5^{\mathrm{a}}$ \\
1910 & 10.1 & 0.4 \\
1921 & 10.1 & $\ldots$ \\
1930 & 9.4 & 2.2 \\
1940 & 9.3 & 3.5 \\
1960 & 17.2 & 5.2 \\
1980 & 24.8 & 11.4 \\
\hline
\end{tabular}

Source: ECLAC and INEGI.

a 1895. 
FIGURE 1

Mexico: Gross domestic product, 1921-1997

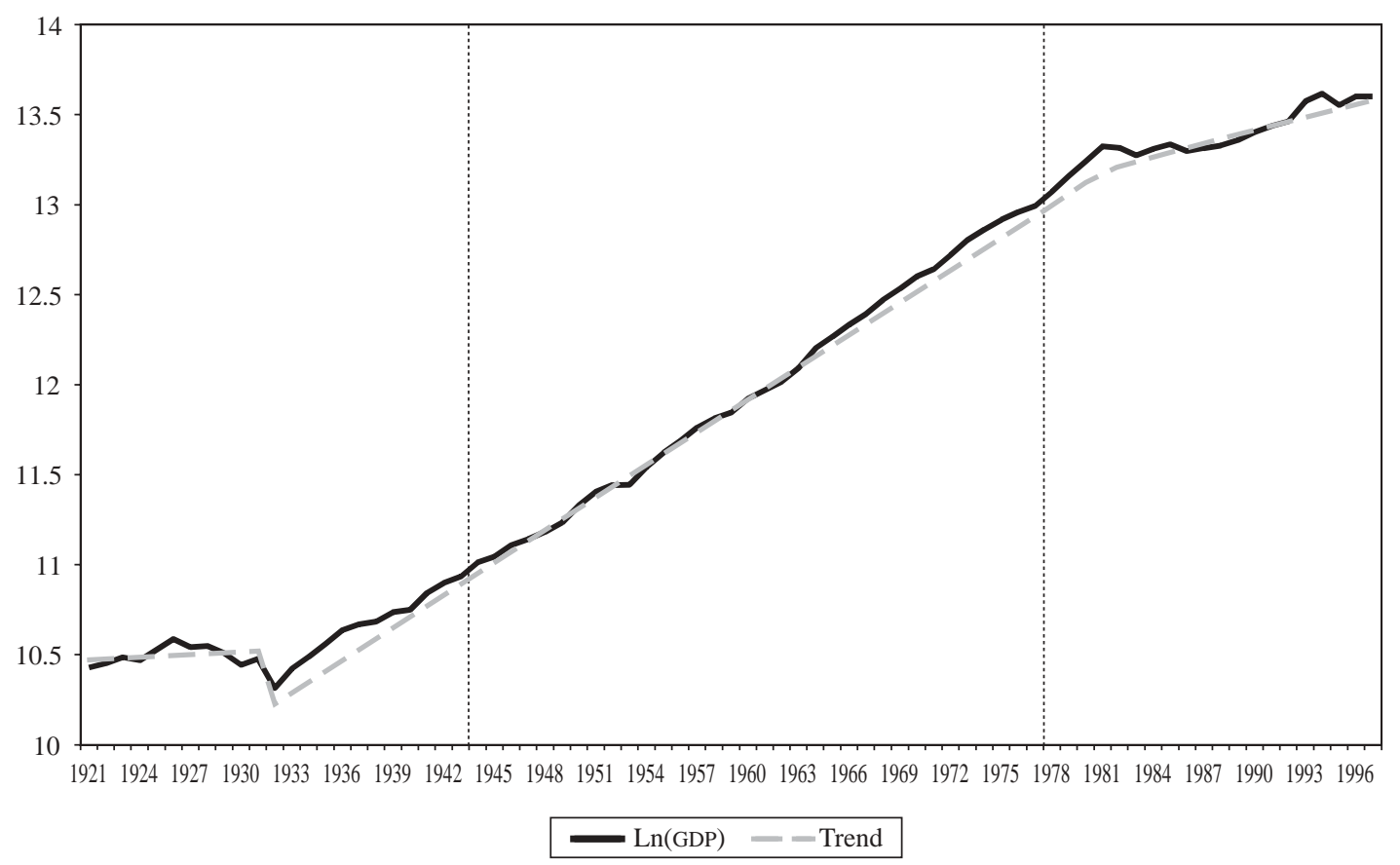

Source: Solís (2000).

in 1980. The average number of years of schooling of the adult population jumped from 2.6 to 7.1 , and life expectancy at birth increased 24 years to 65 (table 3 ). Despite these improvements, however, the benefits of growth were far from being evenly distributed. By the end of the period, $20 \%$ of the population received more than $50 \%$ of total disposable income, while $58 \%$ of Mexicans were still living in a state of poverty. ${ }^{20}$ Thus, at the end of Mexico's Golden Age, poverty and inequality were still major problems to be solved.

The macroeconomic performance from 1940 to 1970 was undoubtedly impressive, and the strategy on which it was based tackled important obstacles on the road to Mexico's development. However, it ignored or underestimated the magnitude of other obstacles.

The first of these obstacles arose from the neglect of agriculture, which, after 1965, faced serious difficulties in expanding production. Its rate of growth in the second half of the 1960s fell below the pace of population expansion. Among the factors explaining

${ }^{20}$ Less conservative estimates put this figure as high as 63\% (see Hernández Laos, 1989). this decline were the dual character of the sector, the adverse trend in the prices of agricultural goods relative to manufacturing goods, and the continuous decline of its share in public investment after the 1950s. All these elements contributed to an increase in poverty, a contraction of the potential domestic market, and a loss of social cohesion which led to emergent social instability.

Secondly, while trade protection proved a valuable instrument for promoting growth and import substitution in many sectors, there was no explicit policy, either from the private or the public sector, to strengthen over time the economy's export potential. Neither was it clear whether the policy as it stood could complete the most difficult phase of import substitution involving high-technology capital goods.

Finally, tax reforms systematically aborted, and public finances became increasingly dependent on external debt. ${ }^{21}$ So too did the balance of payments,

\footnotetext{
${ }^{21}$ By 1972, the debt/GDP ratio and the debt-service/exports ratio had both reached $18 \%$ (compared to $1 \%$ in 1946). While these magnitudes did not yet imply a serious macroeconomic imbalance, they reflect the dynamic evolution of foreign indebtedness during the period.
} 
TABLE 5

Mexico: Structure of GDP, 1895 - 2002

(Percentages)

\begin{tabular}{|c|c|c|c|c|c|c|c|c|c|c|c|c|}
\hline & 1885 & 1910 & 1926 & 1932 & 1940 & 1955 & 1970 & 1970 & 1980 & 1980 & 1990 & 2000-2002 \\
\hline & \multicolumn{7}{|c|}{ (based on 1960 prices) } & \multicolumn{2}{|c|}{ (based on 1980 prices) } & \multicolumn{3}{|c|}{ (based on 1993 prices) } \\
\hline Agriculture ${ }^{\mathrm{a}}$ & 29.1 & 24.0 & 19.7 & 24.1 & 19.4 & 18.3 & 11.6 & 12.2 & 9.0 & 7.1 & 6.7 & 7.6 \\
\hline Mining & 3.0 & 4.9 & 9.3 & 7.2 & 6.4 & 4.8 & 4.8 & 2.5 & 3.3 & 1.4 & 1.5 & 2.1 \\
\hline Industry & 9.0 & 12.3 & 14.7 & 13.3 & 18.7 & 22.1 & 29.7 & 30.1 & 31.9 & 25.0 & 24.1 & 27.0 \\
\hline (Manufacturing) & $(7.9)$ & (10.7) & (11.6) & $(10.2)$ & (15.4) & $(17.5)$ & $(23.3)$ & (23.7) & $(24.9)$ & (19.2) & (19.6) & (21) \\
\hline Services & 58.9 & 58.7 & 56.3 & 55.4 & 55.5 & 54.7 & 53.9 & 55.2 & 55.8 & 66.5 & 67.6 & 63.3 \\
\hline Total & 100 & 100 & 100 & 100 & 100 & 100 & 100 & 100 & 100 & 100 & 100 & 100 \\
\hline
\end{tabular}

Source: Banco de México and INEGI.

a Includes livestock, forestry and fishing.

which became more and more vulnerable to short-term capital flows, with their potentially destabilizing influence. As long as the Golden Age of world economic growth continued, misperceptions regarding the potential importance of these issues could remain. Unfortunately, this Golden Age was coming to an end.

\section{4. "Shared development", the oil boom and the debt crisis}

Insofar as the administrations of the 1970s did not solve these obstacles, they could, and did, become painfully costly. The new Echeverría administration which took office in late 1970 had as a central point of its political platform the claim that the 'stabilizing development' strategy of the 1956-1970 period had failed to address the fundamental problem of inequality. A new strategy of 'shared development' was therefore proposed in which the benefits from economic growth would be more evenly distributed. In practice, however, the policies adopted failed to fulfill this objective.

Temporarily, the strategy did have the intended impact on the functional distribution of income. Gil Díaz (1987) shows that the share of labour in the net national product went up from $40 \%$ in 1970 to $43 \%$ in 1972-1974 and reached 49\% in 1976. In addition, GDP achieved an average rate of growth of $6.1 \%$ per annum. Unfortunately, these achievements were accompanied by the emergence of severe macroeconomic imbalances.

This was due to a number of reasons. On the external front, the collapse of the world's Golden Age took its toll on the Mexican economy. The first oil price shock found Mexico as a net importer of oil and, together with the decline in external demand, tightened the balance of payments constraints on growth. Moreover, the increase in domestic inflation rates to the $20 \%$ range, the expansion of public investment, and a fixed exchange rate tripled the trade deficit between 1970 and 1975. The model of industrialization also began to show some signs of exhaustion. Investment was carried out to modernize plants in old sectors already exposed to foreign competition, but failed both to increase exports significantly and to deepen import substitution in the capital goods sector. Insofar as tax reform was not addressed, public revenues lagged behind. The fiscal deficit climbed from $2.5 \%$ of GDP to $9.9 \%$ between 1971 and 1976, and was increasingly covered through monetary expansion and external debt (which increased at an average annual rate of $40 \%$ from 1973 to 1976$).{ }^{22}$ In addition, private enterprise did not find fertile ground in the 'shared development' rhetoric, and soon the economy's expansion was being driven exclusively by public spending. Eventually, the situation worsened significantly as a result of capital flight. Notwithstanding the increase in import controls and tariffs, balance of payments pressures forced the government to depreciate by nearly $100 \%$ in 1976 , thus abandoning the exchange rate parity that had remained fixed for more than 20 years.

\footnotetext{
22 The belief that development, especially social development, could be accelerated while sacrificing fiscal discipline was rightly criticized by orthodox economists at the time. See Solís (1977) for a forceful statement of this view.
} 
Despite the severity of the 1976 crisis, in a year or so the economy's prospects were completely turned around with the announcement of Mexico's vast oil resources. Their exploitation and sale in the international market brought a swift and strong recovery. The trade deficit was brought under control again, averaging $1.5 \%$ as a share of GDP. The term profile of foreign debt was restructured and, for a while, new indebtedness did not grow noticeably. An ambitious industrialization plan was launched on the assumption of a sustained long-term increase in the price of oil. Manufacturing investment soared, boosted by public and private entrepreneurship, and GDP growth reached rates of $8 \%$ to $9 \%$ per annum between 1978 and 1981. A major tax reform was also carried out in this period, and these changes reduced some of the inequities of the Mexican tax system. ${ }^{23}$

However, with the benefit of hindsight, there were already some worrying signs by the late 1970 s. The inflation rate had reached a plateau of around $18 \%$ and did not show any signs of going down. Interest payments were increasing as nominal rates in the international credit markets floated upwards in an unprecedented way. Few investments were directed to the export sector, although two exceptions are worth noting: the motor-vehicle industry - where a new generation of plants was being built with state-of-theart technology, explicitly designed to compete in world markets - and the petrochemicals sector, where the public sector was investing heavily.

\section{IV}

\section{The shift in the balance between the market and the State since the mid-1980s}

During the 1980s, the Mexican economy was subject to two major external shocks: the 1982 debt crisis which increased debt service and curtailed new external finance, and the 1986 oil price shock which dramatically cut off a major part of the country's main source of foreign exchange and fiscal revenues. These external shocks brought to an end the long period of rapid economic expansion.

By the early 1990s the foreign exchange and fiscal gaps that were opened by the debt crisis and the oil shock had been closed after a succession of orthodox and heterodox attempts at stabilization. In the meantime, a 'great transformation' had been taking place, if we may appropriate the expression that Polanyi used to refer to events of a different scale. Balance of payments liberalization and the North American Free Trade Agreement (NAFTA) have closely integrated the economy with that of the United States, both in terms of trade and capital flows. Foreign participation in the economy has increased through direct investments in new plants, as well as mergers and acquisitions, following the elimination of restrictions on foreign ownership. State banks and public enterprises have, with few exceptions, been transferred into private hands. Privatization revenues, together with debt relief (under the 1989 Brady Plan) and fiscal adjustment, allowed the government to reduce its debt, as a proportion of GDP, to rather low levels by international standards. A market-oriented rural economy emerged following far-reaching changes in the land tenure system, price policies, and the privatization or elimination of State enterprises and their substitution by a combination of subsidies and public programmes. In sum, a massive reform process was carried out with a view to giving a larger economic role to the private sector and greater scope to market forces, and to accelerating integration into the international economy. ${ }^{24}$

\footnotetext{
${ }^{23}$ An adjustment for inflation was introduced in personal income taxation, and a value-added tax and a new corporate income tax were established. The tax base broadened as loopholes were closed, and the whole administrative and control process was simplified. The contribution of the one to five minimum wage bracket to labour income tax collection went down from $58 \%$ in 1978 to $28 \%$ in 1981, while the contribution of the highest wage bracket - more than 15 minimum wages- went up from $8 \%$ to $25 \%$ of the total. For a detailed description, see Gil Díaz (1987).

${ }^{24}$ For a detailed review of the reform process, see Lustig (2002). For an excellent in-depth analysis of the changing pattern and eventual decline of the Mexican Presidents' authoritarian role in the design and implementation of economic policy, see Cordera and Lomelí (2000).
} 


\section{Privatization and economic efficiency}

The case for greater selectivity in State participation in the economy and, indeed, for disengagement by the State from a number of productive activities, has been based on macroeconomic grounds: a government with limited access to credit markets, pressing social needs to be met, and a private sector with ample financial resources abroad ready to be invested in previously State-dominated activities which do not have a high social priority. The case is certainly extremely powerful. But this is so for macroeconomic reasons related to the special conditions of the 1980s and has less significance for the long-term growth potential of the economy, beyond the promise (which so far largely remains just that) of a considerable expansion in human capital investments made possible by the huge privatization revenues.

There is also, of course, the more traditional microeconomic case for privatization based on the notion that greater participation by the private sector will bring about improvements in the overall efficiency of investment. If the latter is a positive function of the share of private investment in overall investment, then part, if not all, of the fall in the overall rate of accumulation could be compensated by a shift in the composition of investment. As shown in table 6, there was indeed a dramatic shift in the composition of investment during the 1980s: the share of the private sector in total fixed investment rose from $56 \%$ in 19801981 to $76 \%$ ten years later and then to $84 \%$ by the late 1990s.

The first point to be made in addressing this issue is to recognize that the efficiency of overall investment does not depend only on its private/public sector composition, but also on the rate of investment itself, which affects investment efficiency through its consequences on the age distribution and the structure of the capital stock (residential/non-residential, net investment/depreciation). Now, as clearly shown also in table 6 , the shift in the private/public composition of investment was a result of the absolute decline in

TABLE 6

Mexico: Structure of gross fixed capital

(Billions of 1993 pesos and percentages)

\begin{tabular}{|c|c|c|c|c|c|c|c|c|c|}
\hline & \multicolumn{9}{|c|}{ Investment } \\
\hline & \multicolumn{3}{|c|}{ Total } & \multicolumn{3}{|c|}{ Public } & \multicolumn{3}{|c|}{ Private } \\
\hline & GDP & Billions & $\%$ of GDP & Billions & $\begin{array}{l}\% \text { of total } \\
\text { investment }\end{array}$ & $\%$ of GDP & Billions & $\begin{array}{l}\% \text { of total } \\
\text { investment }\end{array}$ & $\%$ of GDP \\
\hline 1980 & 948.6 & 206.3 & 21.8 & 88.8 & 43.0 & 9.4 & 117.5 & 57.0 & 12.4 \\
\hline 1981 & 1029.5 & 239.8 & 23.3 & 108.8 & 45.4 & 10.6 & 131.1 & 54.6 & 12.7 \\
\hline 1982 & 1024.1 & 199.6 & 19.5 & 88.3 & 44.2 & 8.6 & 111.3 & 55.8 & 10.9 \\
\hline 1983 & 988.4 & 143.1 & 14.5 & 56.5 & 39.5 & 5.7 & 86.6 & 60.5 & 8.8 \\
\hline 1984 & 1022.1 & 152.3 & 14.9 & 58.8 & 38.6 & 5.8 & 93.5 & 61.4 & 9.1 \\
\hline 1985 & 1044.5 & 164.3 & 15.7 & 59.3 & 36.1 & 5.7 & 105.0 & 63.9 & 10.0 \\
\hline 1986 & 1012.3 & 144.9 & 14.3 & 50.9 & 35.1 & 5.0 & 94.0 & 64.9 & 9.3 \\
\hline 1987 & 1029.8 & 144.7 & 14.1 & 44.6 & 30.8 & 4.3 & 100.1 & 69.2 & 9.7 \\
\hline 1988 & 1043.0 & 162.5 & 15.6 & 40.6 & 25.0 & 3.9 & 121.9 & 75.0 & 11.7 \\
\hline 1989 & 1085.8 & 171.9 & 15.8 & 43.5 & 25.3 & 4.0 & 128.4 & 74.7 & 11.8 \\
\hline 1990 & 1142.0 & 194.5 & 17.0 & 48.4 & 24.9 & 4.2 & 146.1 & 75.1 & 12.8 \\
\hline 1992 & 1232.3 & 239.2 & 19.4 & 47.1 & 19.7 & 3.8 & 192.2 & 80.3 & 15.6 \\
\hline 1993 & 1256.2 & 233.2 & 18.6 & 47.3 & 20.3 & 3.8 & 185.9 & 79.7 & 14.8 \\
\hline 1994 & 1312.2 & 252.7 & 19.3 & 64.9 & 25.7 & 4.9 & 187.9 & 74.3 & 14.3 \\
\hline 1995 & 1230.6 & 179.4 & 14.6 & 44.6 & 24.8 & 3.6 & 134.9 & 75.2 & 11.0 \\
\hline 1996 & 1293.9 & 208.9 & 16.1 & 38.0 & 18.2 & 2.9 & 170.9 & 81.8 & 13.2 \\
\hline 1997 & 1381.5 & 252.8 & 18.3 & 41.8 & 16.5 & 3.0 & 211.0 & 83.5 & 15.3 \\
\hline 1998 & 1449.3 & 278.8 & 19.2 & 38.7 & 13.9 & 2.7 & 240.1 & 86.1 & 16.6 \\
\hline 1999 & 1503.5 & 300.3 & 20.0 & 42.9 & 14.3 & 2.9 & 257.4 & 85.7 & 17.1 \\
\hline 2000 & 1602.3 & 334.4 & 20.9 & 54.5 & 16.3 & 3.4 & 279.9 & 83.7 & 17.5 \\
\hline 2001 & 1597.2 & 314.9 & 19.7 & 47.5 & 15.1 & 3.0 & 267.5 & 84.9 & 16.7 \\
\hline $2002^{\mathrm{a}}$ & 1611.7 & 310.9 & 19.3 & 50.9 & 16.4 & 3.2 & 260.0 & 83.6 & 16.1 \\
\hline
\end{tabular}

Source: ECLAC and INEGI.

a Preliminary figures. 
the rate of public investment, rather than of an absolute increase in private investment: as a fraction of GDP, in the early 1990s the latter was still at approximately the same levels as ten years earlier, and it was only 3 to 4 percentage points higher in 2001-2002. Thus, if the share of private investment in overall investment increased, this was largely due to the collapse of public investment rates. Unless the productivity of public investment was actually negative - and nobody to our knowledge has argued this- the efficiency losses resulting from the absolute fall in the overall rate of investment are bound to outweigh any efficiency gains brought about by the shift in its composition. The rise in the capital/output ratio since 1982 is fully consistent with this conclusion.

In addition, the relationship between the efficiency and the composition of overall investment is undoubtedly more complex than generally assumed. It is likely to have the shape of a Laffer curve, with low efficiency levels being consistent with both too high and too low shares of public investment. This is so because public investment itself, as much recent empirical research suggests, ${ }^{25}$ positively affects the productivity of private investment, and thus at low levels of public investment further reductions can bring about losses rather than gains in overall efficiency. Given the sharp contraction of public investment during the 1980s, and the fact that the microeconomic efficiency gains and performance improvements of the newly privatized enterprises are yet to be seen in most cases, the question arises as to whether the economy moved to the wrong side of the Laffer-type curve. In such circumstances, an increase in public investment in areas with high social returns and high positive externalities for the productivity of private investment is the best way of addressing the problem of investment efficiency.

\section{Trade liberalization, productivity and growth}

The results of the trade policy reform are also controversial. Let us look first at the static efficiency gains expected by classical trade theory. ${ }^{26}$ One of the striking features of the Mexican transition towards a

\footnotetext{
${ }^{25}$ In the literature on public capital, see the studies by Aschauer (1989a, 1989b, 2000), Deno (1988), Munell (1990), and Easterly and Rebelo (1993), among others.

${ }^{26}$ For a detailed discussion of resource reallocation processes see Ros (1992) and, in particular, Moreno-Brid (1988) for an analysis of a most important aspect of these processes: i.e., the restructuring of the automobile industry and its role in the 1980s manufacturing export boom.
}

liberalized trade regime is the smoothness of the microeconomic processes of resource reallocation. The absence of massive reallocation processes is revealed by the fact that current trends in the trade pattern and industrial structure are largely an extrapolation of the past. Beyond a few exceptions — such as the rapid expansion of labour-intensive maquiladora exports in the 1990s - the reallocation processes have witnessed an extrapolation of past trends in the trade and industrial patterns marked by the increasing importance of heavy intermediate goods, consumer durables and capital goods. The counterpart of this smoothness and of the lack of reversal in the direction of structural change in manufacturing is, however, that the classic efficiency gains expected from trade liberalization cannot be very large. For those expecting a large, painful but greatly beneficial reallocation of resources in favour of traditional exportable goods, which are labour- and natural resource-intensive, the experience with trade liberalization to date must have been, in reality, very disappointing.

In our view, two major factors explain these developments. First, and perhaps paradoxically, the adjustment to the debt crisis and declining terms of trade in the 1980s, and then later the adjustment to the 1994-1995 financial crisis, forced macroeconomic policy to provide unprecedented levels of 'exchange rate protection' which facilitated the adjustment of industrial firms to a more open economy. The second is simply Mexico's successful import-substitution experience in the past and the advanced stage that intraindustry (and intra-firm) processes of specialization and trade had already reached by 1980 , including those in the capital-intensive, large-scale manufacturing industries which have been partly responsible for the export boom of the last two decades. The industrial policy reforms of the late 1970 s, especially in the automobile industry, gave a further impulse to those processes. The incentives provided later by a very competitive exchange rate and by the mid-1980s trade reforms thus fell on already fertile ground. The outstanding export performance of Mexico's manufacturing is therefore, to a large degree, a legacy of the import substitution period and highlights in a very real sense its success: it did indeed lead to an irreversible change in the economy's structure of comparative advantages.

What were the dynamic effects of trade liberalization on productivity and growth performance? ${ }^{27}$ In the

\footnotetext{
${ }^{27}$ For a more detailed analysis, see Ros (1992 and 1993).
} 
economy as a whole, labour productivity has stagnated since the early 1980s (compared to a trend growth rate of the order of 4\% per annum between 1950 and 1973 (table 7), and this applies to the periods both before and after the 1985 trade reform. At the same time, growth in manufacturing productivity shows a recovery in the post-trade liberalization period since 1985 compared to the first half of the decade. Although it is difficult to disentangle it from other effects, including those of privatizations, industrial policy and a declining real exchange rate from 1988 to 1994, the contribution of trade liberalization to productivity growth appears to have been positive in a number of manufacturing industries where it has facilitated a greater degree of intra-industry (and intra-firm) specialization or has shaken out less efficient producers. However, the benefits of the greater penetration of imports, in terms of productivity performance, become much more doubtful in other cases, which also show a rapid displacement of local producers resulting from increased exposure to foreign competition. Here, the result of import penetration has been a worsening of both output and productivity performance, whether compared to historical trends or to the period immediately preceding trade liberalization.

Thus, while liberalization in the fields of trade (and foreign investment) have resulted in fast export and labour productivity growth in a limited number of sectors, overall economic growth has remained problematic. GDP growth finally resumed at relatively fast rates from 1996 to 2000, but it did so in an exceptionally favourable international environment,

TABLE 7

Mexico: Employment, working hours and labour productivity

\begin{tabular}{lcccc}
\hline & 1950 & 1973 & 1990 & 1998 \\
\hline $\begin{array}{l}\text { GDP per person employed } \\
\text { Labour productivity }\end{array}$ & 7685 & 18399 & 20747 & 20810 \\
$\begin{array}{l}\text { Employment, as a percentage } \\
\text { of the population }\end{array}$ & 3.6 & 8.9 & 10.1 & 10.0 \\
\hline & 30.8 & 26.3 & 29.4 & 32.0 \\
\hline $\begin{array}{l}\text { Growth of GDP per hour } \\
\text { worked }^{c}\end{array}$ & $1950-$ & $1973-$ & $1973-$ & $1990-$ \\
\hline
\end{tabular}

Source: Maddison (2001).

a In 1990 international dollars.

b GDP per hour worked (1990 international dollars per hour).

c Annual average compound growth rate. and the recovery turned out to be short-lived. The renewed appreciation of the peso eventually slowed down the export boom, and the recession of the United States economy starting in 2001 put an end to the short period of export-led growth. Since 2001 the economy has stagnated and income per capita is very likely to fall in 2003 for the third consecutive year. Rapid and sustained economic growth is yet to be seen.

This experience raises serious doubts about the ability of the current industrial structure to generate self-sustaining growth. The counterpart of the processes of intra-firm and intra-industry trade specialization is that many, if not most, exporting sectors and firms, while dynamic, lack domestic linkages and a number of other industries have witnessed a 'disintegration of linkages' ${ }^{28}$ Moreover, the increasing dominance of the maquiladora industry in export activities is a motive for concern. The maquiladora industry is characterized by a low potential for productivity growth: the counterpart of its high capacity of employment absorption. As the real exchange rate has appreciated again in the recent past and dollar wages have increased, profit margins have declined in the face of low and stagnant labour productivity. This, together with the United States recession, has put a brake on the expansion of production capacity and output in the maquiladora sector and has led to a sharp decline in employment starting in the third quarter of 2000. In the absence of productivity growth, the maquiladoras constitute a sector that can only expand on the basis of low wages. Given the tendency of wages to increase in other sectors along with productivity gains, the maintenance of the 'internal competitiveness' of the maquiladoras, i.e., their capacity to attract resources from the rest of the economy, would require a continuously undervalued currency. ${ }^{29}$

\section{Financial liberalization, the capital surge and the financial crisis}

If the efficiency and productivity effects of the market reforms have been unable to make up for the loss of

\footnotetext{
28 Dussel (2000) illustrates this with a case study of the pharmaceutical industry, where the share of locally produced raw materials fell from around $80 \%$ in the late 1980 s to around $20 \%$ in 1998.

${ }^{29}$ For an analysis of the performance of the maquiladora industry in the 1990s, see Frenkel and Ros (2003).
} 
growth potential during the 1980s, what about their effects on external capital inflows and the prospects for increasing the rate of accumulation by these means? Would the shift in the market/State balance bring about a permanently higher flow of external savings - significantly greater than historical rates - that would allow an increase in the rate of accumulation, despite the sharp decline of the domestic savings rate? Such was the optimistic outlook of many observers in the early 1990s, for whom Mexico — a model reformer and successful emerging market- would turn into a Latin American economic miracle. These optimistic expectations reached their peak when NAFTA was approved in 1993.

The market reforms and positive external shocks, such as the fall in foreign interest rates in the early 1990s, together with the beginning of the NAFTA negotiations, contributed in three main ways to a capital surge from 1990 to 1993 (Ros, 1994). The first was the liberalization of domestic financial markets. The second was a drastic reduction in the country risk premium - an improved image of Mexico as a 'good place to invest' - as a result of the debt relief agreement, the fall in international interest rates and the repayment of foreign debt, financed by the large privatization revenues of 1991-1992. The third, which interacted with the reduction of country risk, was the real appreciation of the peso and the very high interest rates that prevailed in the initial stages of the antiinflation programme of late 1987.

The size and composition of capital inflows, which were heavily biased towards short-term portfolio investments, had three consequences for the economy. First, the continuous appreciation of the real exchange rate, which was taking place in the midst of a radical trade liberalization process, produced a profit squeeze in the tradeable sectors of the economy, with negative consequences for investment (Ros, 2001). Second, as a result of the difficulties in intermediating the massive capital inflows, an allocation of resources biased towards consumption rather than investment (Trigueros, 1998) reinforced the decline in the private savings rate, while the bias towards the production of non tradeable goods, together with the real appreciation, resulted in slow economic expansion. Third, increasing financial fragility, due to the concentration of the inflows in highly liquid assets, accompanied a progressive deterioration of the banking system balance sheets (Trigueros, 1998).

These trends should have given rise to legitimate concern in the field of economic policy. They did not do so, however. By 1993, the current account deficit reached levels of the order of 6-7\% of GDP, and by early 1994 the capital surge was over. Throughout 1994 the authorities financed the massive current account deficit through the depletion of international reserves. Clearly there was an incorrect diagnosis by the government of the causes of the macroeconomic disequilibria, as it was considered that the pressure on the reserves and the dilemmas facing policy makers were temporary and would be corrected without the need for depreciation of the exchange rate. Thus, no significant depreciation of the exchange rate was implemented, on the grounds that it would rekindle inflation and would 'give alarming signs to the market', augment capital flight and trigger a balance of payments crisis. That policy was slowly but steadily being perceived as nonsustainable by investors in Mexico's capital and money markets, however. In the course of the year, the Bank of Mexico not only had to authorize increases in the interest rates on CETES (Treasury Certificates) and Tesobonos (Mexican Treasury Bonds), but also had to allow for greater guarantees on the rates of return on government paper payable in local currency but tied to the nominal exchange rate with the United States dollar. In any case, the foreign exchange reserves kept being depleted, ultimately forcing the authorities to perceive that their macroeconomic policy was unsustainable. At the end of 1994, scarcely a year after NAFTA came into effect, the Mexican economy was in the midst of a financial crisis and on the brink of the worst recession since the Great Depression of the 1930s. Moreover, the country had been experiencing instability and political violence throughout 1994, starting with the armed revolt of the Zapatistas in January (on the same day that NAFTA came into effect).

The boom and bust cycle that culminated with the 1994-1995 banking crisis was a consequence, at least in part, of excessive reliance on financial deregulation and capital market liberalization (Clavijo and Boltvinik, 2000; Lustig, 2002; OECD, 2002). The aftermath of that cycle was a bankrupt banking system whose bailout added some 20 percentage points of GDP to the public debt and left those households and firms-mostly small and medium-sized enterprises with no access to foreign finance- virtually without access to bank credit. It is ironic that the banking sector returned to a situation of credit rationing characteristic of the era of financial repression that preceded the financial liberalization of the late 1980s. This situation has been an obstacle to faster growth and 
has also reinforced the dual structure of the productive sector. $^{30}$

\section{Recent growth and investment performance}

After the decline of $6.2 \%$ in real GDP in 1995 - the sharpest drop in more than fifty years- economic growth resumed in 1996-2000. However, its expansion abruptly stopped in 2001-2002 and per capita GDP actually declined in real terms. On average, from 1985 to 2002 , GDP expanded at an annual rate of $2.2 \%$, or barely half a percentage point above the rate of population growth. Furthermore, the most recent figures indicate that Mexico's per capita GDP remained stagnant in 2003. Thus, at the end of that year, in constant dollars it was little more than $20 \%$ of the U.S. per capita GDP: a gap almost 10 percentage points wider than in 1981 and similar to the level recorded fifty years earlier. In other words, in these five decades the Mexican economy has so far failed to "catch up" in any significant way with its northern neighbour in terms of real per capita GDP.

Crucial to the slowdown in Mexico's rate of economic expansion has been the weak investment performance. ${ }^{31}$ The failure of capital formation to grow at a fast pace - after the years of decline during the debt crisis - has impeded the expansion and modernization of productive capacity and simultaneously restricted the growth of aggregate demand. Indeed, gross fixed investment followed a path similar to that of GDP in real terms. It increased rapidly during the oil boom, then collapsed in 1982-1987, and began a slow recovery in 1988 (figure 2). This rebound gained some strength in 1990-1992 in response to the favourable expectations associated with the beginning of the NAFTA negotiations, only to be cut short in 1995, but it vigorously resumed

FIGURE 2

Mexico: Investment/GDP ratio, 1970-2002 ${ }^{a}$

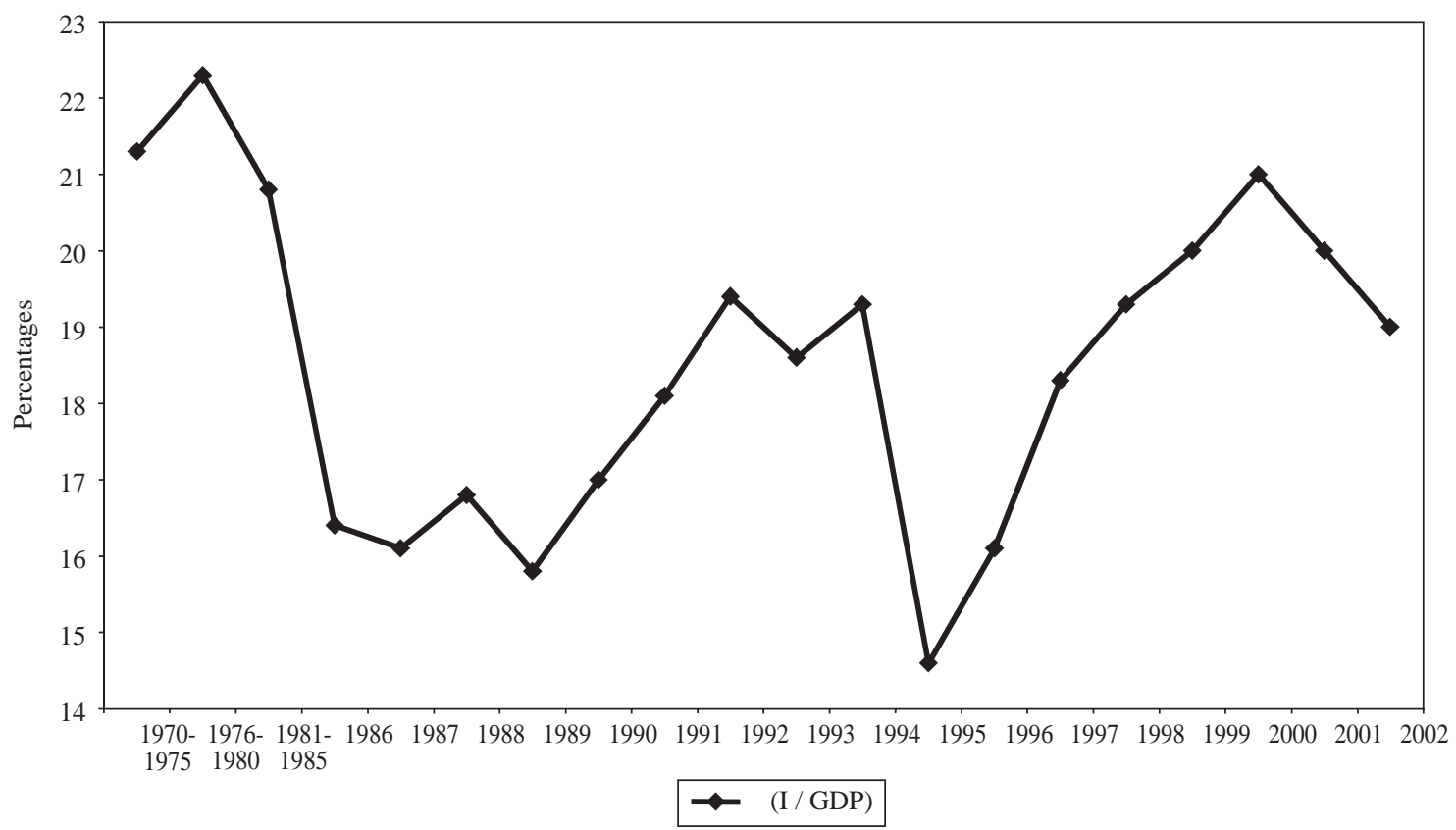

Source: Prepared by the authors from table 4 of Mattar, Moreno Brid and Peres (2003), on the basis of ECLAC and INEGI data.

a The figures for 1970-1988 were calculated on the basis of data in 1980 constant pesos; figures for 1989-2001 were based on data in 1993 constant pesos.

30 Giugale, Lafourcade and Nguyen (2001) and Dussel (2000) document how the credit decline affected large firms and small and medium-sized enterprises differently and the large and increasing gap between the export performance of these two types of enterprises.
${ }^{31}$ For a extensive analysis of the performance of investment in Mexico's manufacturing sector after the macroeconomic reforms see Moreno-Brid (1999) and Mattar, Moreno-Brid and Peres (2003). 
in 1996-2000. However, in 2001-2002 investment again fell in real terms. In synthesis, during the last two decades the investment process has been wanting.

The disappointing performance of investment gives grounds for concern over Mexico's future economic growth. What are the causes behind it? Were there any limitations or shortcomings in the macroeconomic reforms that failed to consider or misperceived the nature of key determinants of Mexico's investment process? Recent research on the topic has identified a set of factors that help explain Mexico's poor investment performance (Mattar, Moreno-Brid and Peres, 2003).

First, the reforms were adopted in a stagnant economy with severely rationed access to foreign or domestic capital and finance. The adverse economic environment was aggravated by the fall in public investment, because "crowding in" between public and private investment has historically been more important than "crowding out" effects (UNCTAD, 2003).

In addition, the reforms had the explicit goal of eliminating all types of incentives, including measures to promote domestic investment (both aggregate and in specific sectors). No attempt was made to orient domestic spending towards investment as opposed to consumption expenditure. Such explicit refusal to promote investment was combined with the uncertainty inherent in any radical change in development strategy. Not surprisingly, such uncertainty was far from favourable to investment, thus leading to the postponement or interruption of investment projects. The elimination of sectoral incentives had an especially strong adverse impact on manufacturing investment, given that manufacturing had traditionally been the most favoured sector under the previous development model based on import substitution and State-led industrialization. This lack of incentives - exacerbated by the intense and sudden competition from imports - reduced manufacturing's relative rate of return, which in turn curbed investment. The appreciation of the real exchange rate in 1988-1994 vis a vis the United States dollar further conspired against investment in manufacturing and, more generally, in the tradeable goods sectors as a whole. While real exchange-rate appreciation can encourage fixed investment in developing countries by lowering the relative prices of imported machinery and equipment, it also shifts relative prices in favour of non-tradeables, inducing a reallocation of labour and investment away from the production of tradeable goods and services. This latter effect appears to have predominated in the Mexican case.

\section{State reform and the tasks of development policy}

The other side of market reform is the retreat of the State and its restructuring. By shrinking in size, there is a better chance that the State will be able to do a better job in its priority tasks. Or so the argument goes. However, the mere fact that the State is smaller does not necessarily mean that it will be more effective. The tax burden in Mexico continues to be extremely low by international standards (OECD, 2002). At $12 \%$ of GDP in the late 1990s, tax revenues are below those of Latin American countries with similar per capita income and well below those of OECD countries. As a result, the fiscal accounts continue to be highly vulnerable to changes in oil income, which still represents around a third of total government revenues. Together with the loss of policy instruments and the reorientation of monetary policy from growth to purely stabilization objectives, as well as the volatility of external capital flows, this gives rise to a major macroeconomic problem, since it contributes to pro-cyclical macroeconomic policies that exacerbate the negative effects of shocks on economic activity.

Nor is the State necessarily more efficient. Despite (or perhaps because of) its massive character, Mexico's fiscal adjustment did not encourage greater internal efficiency of the public sector. Especially before 1985, fiscal adjustment was, by and large, achieved through deep cuts in public investment and the real salaries of public employees: hardly the best way of improving the efficiency of the State and its bureaucracy. Moreover, the retreat of the State has gone well beyond areas where the private sector has a comparative advantage. In fact, public infrastructure investment has been the main victim of fiscal adjustment in the context of falling oil prices. Giugale, Lafourcade and Nguyen (2001) strikingly illustrate with two figures the close correlation between oil price declines, fiscal deficit cuts and reductions in public investment (the correlation coefficient between the last two was 0.82 over the period from 1980 to 1997). As a result, public investment was barely 3\% of GDP in 2001-2002, compared with 5\% in 1994 and 10\% in 1980-1981 (table 6). It is also clear that, despite some positive recent trends in social spending, State disengagement has not served its main stated purpose: the expansion of social infrastructure. The main contribution of privatization revenues was to support stabilization efforts (very effectively, no doubt) by temporarily compensating for the fall in the inflation tax and 
strengthening the capital account of the balance of payments through the financial assets that the private sector had to bring back home to purchase the public enterprises on sale.

The implications of all this are more important than is generally acknowledged because the priority tasks of the State - social policy in particular- are today far more formidable than in the past. This is so for several reasons. There is, first, the accumulated backlog of unmet social needs and the legacy of increased inequality from the 1980s. In the face of slow growth in agriculture and the expansion of the urban informal sector, the recovery of social spending in the 1990s has not prevented an increase in the number of poor and a persistently high level of inequality in income distribution. Lustig (2002) shows that income inequality, as measured by the Gini concentration coefficient, increased quite sharply from 1984 to 1989 (around four percentage points) and then fell from 1989 to 1994 (although remaining slightly above its 1984 level). Since then, however, the OECD (2002) estimates show a slight increase in income inequality between 1994 and 2000, with the Gini coefficient rising from 0.477 to 0.481 . Poverty rates (both extreme and moderate) show a similar behaviour across time, while the number of poor shows a continuous increase through 1994.

Secondly, there are at least two ways in which the present development pattern is exacerbating social disparities. The State's retreat from agriculture and the reform of the land tenure system may have brought private capital and prosperity to some rural areas, but they have also inadvertently tended to impoverish large masses of rural workers in a similar way that agricultural modernization under the Porfiriato did deliberately and on a much more massive scale. There has been a clear difference between the behaviour of the commercial sector producing exportable goods - which benefited from and responded positively to the reforms (exports have grown by $70 \%$ during the first five years of NAFTA) - and the ejido sector which has not done so (imports grew by $60 \%$, adversely affecting this sector which largely produces importable goods). Today, this sector barely survives through increasing integration into off-farm activities, with about $40 \%$ of its income coming from non-farm sources, including remittances (Giugale, Lafourcade and Nguyen, 2001). As those authors acknowledge, the overall stagnation of agricultural output and the persistency of rural poverty are related to the reforms themselves. The downward trend in real agricultural prices throughout the 1990s was strengthened by the removal of trade protection (and exchange rate overvaluation in the early part of the decade). The elimination of extension programmes and technical assistance has affected a large proportion of small producers. The retreat of the State from distribution was followed by the domination of marketing channels by oligopolistic intermediaries who depress the prices obtained by producers, affecting particularly the poorest areas. In the absence of competitive markets, and without proper consideration of the large regional diversity and income heterogeneity of the Mexican countryside, liberalization did not yield the expected benefits.

On the other hand, the benefits of greater integration with the international economy, and with the United States in particular, are also being very unevenly distributed within the country. Greater integration has been accompanied by a substantial increase in the wage premium on skilled labour, with a resulting relative decline in unskilled labour incomes: a major cause of persistent inequality. As documented by Godínez (2000) and Dussel (2000), general regional trends from 1970 to 1985 pointed towards a deconcentration of economic activity (away from the main industrial centres in the metropolitan area of Mexico City, Nuevo León and Jalisco) and convergence of regional income levels. Since 1988, however, a process of divergence has been taking place, especially as the northern states linked to export activities have been rapidly increasing their share in national income. By contrast, the relatively poor South (with the exception of Quintana Roo, which has benefited from the expansion of tourism) has been lagging behind. These regional trends are clearly linked to the economy's structural changes, such as the lagging cereal agriculture, expanding export sectors of agro-industrial products, fruit and vegetables, and the rapidly growing export-oriented manufacturing activities in the Northern and Central areas. Just as in the late 18th century the 'opening of North Atlantic trade' exacerbated the 'fragmentation of regional markets', there is today a tendency towards a deepening of regional disparities, especially between a prosperous north increasingly integrated with the United States economy and a poor and backward south plunged into agricultural stagnation.

Finally, but no less importantly, by abandoning the trade and industrial policy instruments that have worked successfully in the past without seeking 
effective replacements for them, current development strategy encourages the exploitation of present rather than potential comparative advantages. The basic task of development policy - the task of changing and enhancing the present endowment of resources and, over time, shifting the pattern of comparative advantages towards higher value-added, technologyintensive activities - now falls entirely, in the absence of an industrial policy, upon social policies. A proportionate response to this challenge could improve the situation more than the application of an active industrial policy with little social policy, but our point is that the challenge itself is much bigger and the response remains to be seen. In contrast, a less than proportionate response would lead to freezing the present stage of development - getting stuck in the relatively unskilled and poorly paid activities that form part of the production processes of capital-intensive industries. This is a far from desirable prospect for a country that needs to grow fast in order to raise the living standards of its 100 million people.

\section{$\mathrm{V}$}

\section{Concluding remarks}

All this leads us to the final and most important aspect of the overall reform process, regarding which we can only pose the following questions: Is the shift in the market/State balance a sign that, after having reduced economic backwardness through State-sponsored industrialization, the use of a different set of ideas would be more appropriate in the new stage: a shift that would be the natural companion of the transition from Gerschenkronian to Schumpeterian entrepreneurship? Or is it still the case that 'to break through the barriers of stagnation in a backward country, to ignite the imaginations of men, and to place their energies at the service of economic development, a stronger medicine is needed than the promise of better allocation of resources...'? (Gerschenkron, 1952). Dealing with these questions falls outside the scope of this paper, and of the wisdom of its authors. But on the answers to them depend Mexico's longer-term prospects for rapid economic development.

What we can say, however, is that the origin of the adjustment problems and the new problems created by the reform process are not being adequately perceived in current development policy. First, the notion that the crisis was brought about by the exhaustion of past development strategies should not be taken for granted, even though we would be very far from defending every single aspect of past development strategies. Secondly, the solution to the new obstacles may require more and better, rather than less, State participation in the economy. As we have tried to show, the source of these new problems must be sought in part in the retreat of the State in such areas as public infrastructure investment. But as a result of the shift in ideological climate, very little attention is being given to these problems and to what government policy can do about them, while at the same time too much is expected from the efficiency gains of market reforms. Is it the case that, just as occurred a century and a half ago, the real obstacles to economic development are being misperceived?

(Original: English)

Bibliography

Aschauer, D.A. (1989a): Is public expenditure productive?, Journal of Monetary Economics, vol. 23, No. 2, Rochester, Simon Graduate School of Business Administration, University of Rochester.

(1989b): Does public capital crowd out private capital?, Journal of Monetary Economics, vol. 24, No. 2, Rochester, Simon Graduate School of Business Administration, University of Rochester.
(2000): Public capital and economic growth: issues in quantity, finance and efficiency, Economic Development and Cultural Change, vol. 48, No. 2, Chicago, The University of Chicago Press.

Beatty, E. (2001): Institutions and Investment, Stanford, Stanford University Press.

(2002): Commercial policy in Porfirian Mexico: the structure of protection, in J.L. Bortz and S. Haber, The Mexican 
Economy, 1870-1930. Essays on the Economic History of Institutions, Revolution and Growth, Stanford, Stanford University Press.

Bortz, J. and S. Haber (2002): The Mexican Economy, 1870-1930. Essays on the Economic History of Institutions, Revolution, and Growth, Stanford, Stanford University Press.

Cárdenas, E. (1985): Algunas cuestiones sobre la depresión mexicana del siglo XIX, Revista latinoamericana de historia económica y social, No. 3, Lima.

Cárdenas, E. and C. Manns (1989): Inflación y estabilización monetaria en México durante la revolución, El trimestre económico, vol. 56, No. 221, Mexico City, Fondo de Cultura Económica, January-March.

Clavijo, F. and J. Boltvinik (2000): La reforma financiera, el crédito y el ahorro, in F. Clavijo (ed.), Reformas económicas en México 1982-1999, Lecturas El trimestre económico, No. 92, Mexico City, Fondo de Cultura Económica.

Coatsworth, J. (1978): Obstacles to economic growth in nineteenthcentury Mexico, The American Historical Review, vol. 83, No. 1, Washington, D.C., American Historical Association, February.

(1989): The decline of the Mexican economy, 1800-1860, in R. Liehr (ed.), América Latina en la época de Simón Bolivar, Berlin, Colloquium Verlag.

(1990): Los orígenes del atraso. Nueve ensayos de historia económica de México en los siglos XVIII y XIX, Mexico City, Alianza Editorial Mexicana.

Cordera R. and L. Lomelí (2000): Sobre el presidencialismo económico y su crepúsculo, Comercio exterior, vol. 50, No. 11, Mexico City, Banco Nacional de Comercio Exterior, November.

Deno, K.T. (1988): The effect of public capital on U.S. manufacturing activity: 1970 to 1978, Southern Economic Journal, vol. 55, Oklahoma, Southern Economic Association.

Dussel Peters, E. (2000): Polarizing Mexico. The Impact of Liberalization Strategy, Boulder, Colorado, Lynne Rienner Publishers.

Easterly, W. and S. Rebelo (1993): Fiscal policy and economic growth: an empirical investigation, Journal of Monetary Economics, vol. 32, No. 3, Rochester, Simon Graduate School of Business Administration, University of Rochester.

Frenkel, R. and J. Ros (2003): Macroeconomic policies, trade specialization, and labor market adjustment in Argentina and Mexico, University of Notre Dame, unpublished.

Garcia Alba, P. (1974): Los liberales y los bienes del clero, Mexico City, El Colegio de México.

Gerschenkron, A. (1952): Economic backwardness in historical perspective, in B. Hoselitz (ed.), The Progress of Underdeveloped Countries, Chicago, University of Chicago Press.

Gil Diaz, F. (1984): Mexico's path from stability to inflation, in A. Harberger (ed.), World Economic Growth, San Francisco, Institute for Contemporary Studies.

Giugale, M., O. Lafourcade and V.H. Nguyen (eds.) (2001): Mexico: A Comprehensive Development Agenda for the New Era, Washington, D.C., World Bank.

Godínez, V.M. (2000): La economía de las regiones y el cambio estructural, in F. Clavijo (ed.), Reformas económicas en México, 1982-1999, Lecturas El trimestre económico, No. 92, Mexico City, Fondo de Cultura Económica.

Haber, S. (1989): Industry and Underdevelopment: The Industrialization of Mexico, 1890-1940, Stanford, Stanford University Press.

Hernández Laos, E. (1990): Política de desarrollo industrial y evolución de la productividad total de los factores en la industria manufacturera mexicana, Report presented to the Fondo de Estudios Ricardo J. Zevada, Mexico City, Universidad Autónoma Metropolitana.

INEGI (National Institute of Statistics, Geography and Information) (1985): Estadísticas históricas de México, Mexico City
King, T. (1970): Mexico: Industrialization and Trade Policies since 1940, Oxford, Oxford University Press.

Kuntz Ficker, S. (2002): Institutional change and foreign trade in Mexico, 1870-1911, in J.L. Bortz and S. Haber, The Mexican Economy, 1870-1930. Essays on the Economic History of Institutions, Revolution and Growth, Stanford, Stanford University Press.

Lustig, N. (2002): México: hacia la reconstrucción de una economía, Mexico City, El Colegio de México/Fondo de Cultura Económica.

Maddison, A. (1989): The World Economy in the 20th Century, Paris, OECD Development Centre.

(2001), The World Economy: A Millennial Perspective, Paris, Organisation for Economic Co-operation and Development (OECD).

Manzanilla Schaffer, Y. (1963): Reforma agraria en México, in México: 50 años de revolución, Mexico City, Fondo de Cultura Económica.

Moreno-Brid, J.C. (1988): The Motor-Vehicle Industry in Mexico in the Eighties, Geneva, International Labour Organisation (ILO).

(1999): Mexico's economic growth and the balance of payments: a co-integration analysis, International Review of Applied Economics, vol.13, No. 2, London, Routledge.

Moreno-Brid, J.C. and E. Pérez (2003): Trade liberalization and economic growth in Central America, CEPAL Review, No. 81, LC/G.2216-P, Santiago, Chile, December.

Moreno-Brid, J.C. and J. Ros (1994): Market reform and the changing role of the State in Mexico: a historical perspective, in A. Dutt, K. Kim and A. Singh (eds.), The State, Markets and Development, Cheltenham, Edward Elgar Publishing.

Mosk, S. (1950): Industrial Revolution in Mexico, Berkeley, University of California Press.

Munnell, A. (1990): How does public infrastructure affect regional economic performance?, in A. Munnell (ed.), Is there a Shortfall in Public Capital Investment?, Conference Series, No. 34, Boston, Federal Reserve Bank of Boston.

Newell, R. and L. Rubio (1984), Mexico's Dilemma: The Political Origins of the Economic Crisis, London, Westview Press.

Nugent, J.B. (1973): Exchange rate movements and economic development in the late XIX Century, Journal of Political Economy, vol. 84, No. 5, Chicago, The University of Chicago Press, September-October.

OECD (Organisation for Economic Co-operation and Development) (2002): OECD Economic Surveys, Paris.

Polanyi, K. (1944): The Great Transformation, New York, Farrar and Rinehart, Inc.

Ros, J. (1992): Mexico's Trade and Industrialization Experience since 1960: a Reconsideration of Past Policies and Assessment of Current Reforms, Helsinki, World Institute for Development Economics Research (WIDER).

(1993): Trade Liberalization with Real Appreciation and Slow Growth: Sustainability Issues in Mexico's Trade Policy Reform, Helsinki, World Institute for Development Economics Research (WIDER).

(1994): Financial markets and capital flows in Mexico, in J.A. Ocampo and R. Steiner, Foreign Capital in Latin America, Washington, D.C., Inter-American Development Bank (BID). (2001): Del auge de capitales a la crisis financiera y más allá: México en los noventa, in Ricardo Ffrench-Davis (ed.), Crisis financieras en países "exitosos", Santiago, Chile, ECLAC/McGraw Hill.

Rosenzweig, F. (1965): El desarrollo económico de México de 1877 a 1911, El trimestre económico, vol. 32, No. 5, Mexico City, Fondo de Cultura Económica.

Solis, L. (1977): A Monetary Will-O'the Wisp: Pursuit of Equity through Deficit Spending, Geneva, International Labour Organisation (ILO). 
(2000): La realidad económica mexicana: retrovisión y perspectivas, Mexico City, Fondo de Cultura Económica.

Thomson, G. (1986): The cotton textile industry in Puebla during the eighteenth and early nineteenth centuries, in N. Jacobsen and H.J. Puhle (eds.), The Economies of Mexico and Peru during the Late Colonial Period, 1760-1810, Berlin, Colloquium Verlag.

Trigueros, I. (1998): Flujos de capital y desempeño de la inversión: México, in R. Ffrench-Davis and H. Reisen (eds.), Flujos de capital e inversion productiva: lecciones para América Latina, Santiago, Chile, ECLAC/OECD, McGraw-Hill.

UNCTAD (United Nations Conference on Trade and Development) (2003), Trade and Development Report, 2003, UNCTAD/TDR/2003,
New York, United Nations. United Nations publication, Sales No. E.03.II.D.7.

Van Young, E. (1981): Hacienda and Market in Eighteenth Century Mexico: The Rural Economy of the Guadalajara Region, 1675-1820, Berkeley, University of California Press.

(1986): The age of paradoxes: Mexican agriculture at the end of the colonial period, 1750-1810, in N. Jacobsen and H.J. Puhle (eds.), The Economies of Mexico and Peru during the Late Colonial Period, 1760-1810, Berlin, Colloquium Verlag.

Zabludovsky, J. (1994): La depreciación de la plata y las exportaciones, in E. Cárdenas (ed.), Historia económica de México, Lecturas El trimestre económico, No. 64, Mexico City, Fondo de Cultura Económica. 